\title{
Advice-Giving in Roman Comedy: Speech-Act Formulation and $\mathrm{Im} /$ politeness
}

\author{
Łukasz Berger
}

\section{$1 \quad$ Introduction}

The present chapter examines several pragmatic aspects of giving advice in Roman comedy, a speech act particularly concerned with the speakers' selfrepresentation and their social bonds during critical moments of the plot. While orders and threats are mechanisms of exerting power and dominance, good advice in comedy serves to portray father-son and amical relations on stage (Raccanelli 1998: 190). On the other hand, seeking, giving, and receiving advice-planned over many utterances - comprises entire scenes, in which interlocutors manage rapport, while the pragmatic meaning emerges from the on-going interaction. Accordingly, the studies on advice describe multiple possibilities of expressing advice and acknowledge 'a certain fuzziness of the concept itself' (Locher 2012: 7), which is also recognised in Latin scholarship (e.g. Unceta Gómez 2009: 33-34; Barrios-Lech 2016: 274). The following pages set out to address the complexity of the phenomenon of advising in Plautus and Terence, its discursive realisation and its contribution to the Latin system of politeness, as represented in the comedy texts. To this end, I will need to combine various pragmatic perspectives. The speech-act theoretical description of advising (Section 2) will be followed by its analysis in light of the research on im/politeness (Section $3-4$ ). In doing so, I am most indebted to two studies on Latin directives and their im/politeness value: Risselada (1993) and Barrios-Lech (2016). ${ }^{1}$ The existing accounts, arguably, can be further developed by a data-driven analysis of Latin conceptualisations of advising and its consequences for the management of social relations.

In addition, the formulation of speech acts will be investigated in relation to their position within an interaction (Section 5 ) as described by Conversational

1 Cabrillana (2016) combines pragmatics with a sociolinguistic approach to all directive subtypes in one comedy. For studies on Latin requests, see Dickey (2012, 2016). According to Unceta Gómez (2018:13), the directive speech acts are a quintessence of face-threatening acts (see Section 3) and, hence, they are a core issue for the im/politeness studies also in Classical languages. 
TABLE 1 Giving advice in twelve comedies by Plautus and Terence

Plautus Terence Total

\begin{tabular}{llrr}
\hline advisory episodes & 41 & 53 & $\mathbf{9 4}$ \\
turns of advising & 60 & 73 & $\mathbf{1 3 3}$ \\
advisory acts & 75 & 79 & $\mathbf{1 5 4}$ \\
\hline
\end{tabular}

Analysis. ${ }^{2}$ I am also interested in how the act of advising is carried out, starting from the beginning of the adviser's turn. Thus, I shall make a distinction between advisory acts, which are linguistic expressions of a particular piece of advice, and turns of advising, i.e. stretches of talk, carried out by one speaker, which host the advisory act(s). The whole situation of giving advice in one interaction, moreover, will be treated as an episode-this can take the form of a single act (in one turn) or an entire sequence of advising, planned across one or many turns. In order to obtain a more balanced corpus of both authors, to the six plays by Terence I have added six of Plautus' comedies from which I intend to retrieve my data. ${ }^{3}$

As Table 1 shows, the overall number of acts in both authors' corpus are fairly similar, while the selected Plautine comedies seem to contain fewer advisory episodes. On the basis of this limited corpus, I will attempt to establish what types of advisory situation show the highest degree of imposition and how the interpersonal tensions influence both the linguistic expression of the acts and their conversational sequencing.

\section{Advising as a Directive Sub-type}

According to most typologies, advising belongs to a wider group of directives, i.e. speech acts by which the speaker attempts to change the hearer's actions. ${ }^{4}$

2 Hoffmann (1983) first adapted the tools of Conversational Analysis to Roman comedy dialogues, whereas Müller (1997) offered the first systematic account for the dialogues in Terence. See Schegloff (2007) for a comprehensive introduction to the methodology.

3 The two authors, in fact, differ in their storylines and their pursuit of comic effect, as is also visible in their favourite set of stock-characters. For Plautus, I have selected Casina, Curculio, Epidicus, Menaechmi, Stichus, and Trinummus. If it seems profitable, I will sporadically recur to examples from the rest of the plays.

4 Austin (21975: 155-157) mentions the act of advising as pertaining to his group of exercitives, 
The persuasion may take various forms and degrees. Searle (1969: 67) constructs his rule-based definition of advice out of two elements: by advising some future act, the adviser must have some reason to believe that the recipient (from here on: the advisee) will benefit from carrying it out, whereas it is not obvious for either of them that the advisee would carry it out in the normal course of events (i.e. without the advice being given). On the other hand, advice differs from 'stronger' directives such as requests or orders since, as Searle points out, '[a]dvising is more like telling you what is best for you'. From this follows that there is a connection between advice and opinions, assessments, or judgments. Bach and Harnish (1979:49), for instance, point out that 'what the speaker expresses is not the desire that [the hearer] do a certain action but the belief that doing it is a good idea, that it is in [the hearer's] interest'.

The ambiguous status of advisory illocutions will be better explained if, following Risselada (1993: 33), one opts for a prototype classification of speech acts. In her view, advising is a less prototypical member of the directive group; some scholars place it halfway towards assertives, i.e. acts which describe the state of affairs. Accordingly, the uptake of advice, apart from signals of compliance (see tuo consilio faciam in [3]), often includes elements of appreciation and evaluation (see bene mones in [1]), the latter being also a typical reaction to opinions and statements.

The directive sub-type of advising may be further characterised by applying Risselada's (1993: 46-47) criteria of (i) benefit and (ii) bindingness. Accordingly, the future action contained in advice (i) serves the interest of the addressee and (ii) is more optional than orders but more binding than suggestions. Both parameters, however, are not to be understood as fixed in advance or static. In example [1], the old citizen, Periplectomenus, manages to convince the slave, Sceledrus, that his previous accusations towards his neighbour's girlfriend are false. After the servant has apologised, his interlocutor advises him rather insistently to be more discreet from now on. Sceledrus believes in the senex's good intentions, so he takes his words for good advice (bene me mones). The spectators know, however, that Periplectomenus, by persuading the servant to keep his mouth shut, is solely serving his own interest, i.e. he wants to stop the slave from exposing the girl.

which were later included, along with some behabitives, in Searle's (1976: 11) directives. In the typology proposed by Risselada (1993: $36-37$ ), directives may be classified as speech acts about action oriented towards the addressee.

5 Searle (1969: 67). 


\section{[1] Plautus Miles gloriosus 570-573}

Per. ... ignoscam tibi istuc. Sce. at tibi di faciant bene!

Per. ne tu hercle, si te di ament, linguam comprimes, posthac, etiam illud quod scies nesciueris nec uideris quod uideris. Sce. bene me mones. ${ }^{6}$

Per. ... I'll forgive you for this.

Sce. May the gods bless you!

Per. Seriously, if the gods love you, you'll keep your mouth in check. From now on don't know even what you do know and don't see what you do see.

Sce. You're giving me good advice.

In another excerpt, the parasite Peniculus, after having been asked for advice by a high-status Roman matrona, modifies the level of bindingness during the progression of his turn. He formulates a directive act in the subjunctive and then adds a hedge sic censeo 'that's what I think', as if he wanted to reformulate the utterance as an assertive act. Thus, by stressing the subjectivity, Peniculus manages to lower the peremptoriness of his own advice.

[2] Plautus Menaechmi 568-569

Mat. quid ego nunc cum illoc agam?

Pen. idem quod semper: male habeas; sic censeo.

Mat. What should I do with him now?

Pen. The same as always: give him a hard time. That's what I think.

Examples like this show that the optionality and the benefit of the action conveyed in directive sub-types depend on the perception of the participants (see [1]). During the ongoing interaction, that perception may be subject to readjustment (see [2]) and negotiation. In order to grasp this phenomenon, we need to be aware when adopting the prototype approach that there is a 'gradual transition from one speech act [sub-] type to another' (Risselada 1993: 34). Bach

6 Plautus' text and its English translation follow the edition by de Melo (2011-2013). For Terence, I have used Barsby (2001). I will not modify the translations, even though in many occasions the translator's interpretation of the illocutionary force (and the tone of the whole interaction) is different from this presented in the main argument. 
(i) bindingness: BINDING OPTIONAL

(ii) benefit:

SPEAKER $\left\{\begin{array}{c}\text { supplicate } \\ \text { ADDRESSEE }\end{array} \quad \begin{array}{c}\text { advisory acts: } \\ \text { instruct }- \text { admonish - advise - counsel - suggest }\end{array}\right.$

FIGURE 1 Advisory acts in the classification of directives MODIFIED FROM RISSELADA (1993: 48)

and Harnish (1979: 49), for instance, propose a general group of 'advisories' in which they include admonishing, counselling, recommending, urging, and warning. In this paper, I will focus on a similar chain of advisory acts that are differentiated according to the degree of compliance they demand (see Figure 1$) \cdot{ }^{7}$

In spite of using the English speech-act denominations, I will seek, whenever it is possible, to apply a native speaker's taxonomy, retrieved in a bottom-up analysis of the corpus. ${ }^{8}$ Therefore, in order to distinguish particular illocutions, I will take as a starting point the participants' pragmatic metalanguage, i.e. how the interlocutors denominate or describe their own speech activity. Other indications will be provided by further linguistic (e.g. verbal surrounding) and contextual (e.g. type of the interlocutors' relation) cues. ${ }^{9}$

Firstly, Risselada (1993: 48) is right in placing advice 'on the binding side of the scale', but - as will be demonstrated in the following section - this feature depends on other contextual factors such as the authority and the expertise of the adviser, either presupposed or emerging during the interaction. I will start with the speech act covered by the Latin consilium; this type of advice concerns a more symmetrical relation among interlocutors, who, in a troublesome situation, consult one another in search of a solution. This would be the case of the slave Trachalio (see [3]), who accepts the advice (consilium) from another low-status character, even if he himself had a different idea initially. It seems important, nonetheless, that consilium is usually presented as a new

7 Barrios-Lech (2016: 274) chooses to use a wider definition of advice, pointing out that the distinction with suggestions 'proved difficult to make'. My advisory acts, however, will also include instructions and warnings.

8 Using only lay categories, recognised and used by the non-expert participants in conversations, is one of the main premises of the ethnomethodologists and, later on, conversation analysts (see Levinson 1983: 294-296 for a short overview).

9 Compare the methods described by Barrios-Lech (2016: 30-31). 
plan that is yet to be discovered (see reperiamus in [4]). Accordingly, this type of act is connected to the adviser's sphere of expertise (see tuo consilio faciam in [3]), which is understood in relative terms as a level of competence in offering advice claimed for oneself or attributed by others. ${ }^{10}$ Moreover, in a peer-to-peer interaction, this type of advisory episode often entails some further negotiations (see [3] and the continuation of [4]).

[3] Plautus Rudens 96o-962

Tra. ... quid inde aequom est dari mihi? dimidium uolo ut dicas. Grip. immo hercle etiam amplius, nam nisi dat, domino dicundum censeo. Tra. tuo consilio faciam. ${ }^{11}$

Tra. ... What is a fair part I should be given from it? I want you to say half.

Gr. No, even more: if he doesn't give it to you, I think the owner has to be told.

Tra. I'll follow your advice.

[4] Plautus Epidicus 255-256

Per. quid ego faciam? nunc consilium a te expetesso, Apoecides.

Ap. reperiamus aliquid calidi, conducibilis consili.

Per. What should I do? Now I'm seeking your advice, Apoecides.

Ap. Let's find some fresh, expedient plan.

As for monere - another frequent lay denomination of advisory acts - it has a different semantic content. Given its etymological connection with 'memory' (memoria) and 'remembering' (meminisse), this speech act sub-type frequently

10 Thus, it would correspond to Heritage's (2012: 7) relative epistemic status defined 'as a consensual and thus effectively "real" state of affairs, based upon the participants' valuation of one another's epistemic access and rights to specific domains of knowledge and information.'

11 It seems important to add that in this passage the low-status characters do not know each other (cf. Plaut. Rud. 938-958). Trachalio asks Gripus for advice-supposedly—in an unrelated matter which, as it turns out, concerns his interlocutor (962a-963). Hence the (relative) expertise in advising is attributed by Trachalio to his addressee in order to be used, later on, against Gripus' own benefit. 
appears when advisers indicate the solution by simply reminding their interlocutors of the correct way of acting. ${ }^{2}$ Thus, depending on the situation, the act can be understood as an unnecessary admonishment (see [5]) or as good advice (see [6]). On the other hand, monere also encompasses warnings, where the speaker presumes the presence of some likely source of danger or trouble for [the hearer]' (Bach and Harnish 1979: 49)-Periplectomenus in [1] may serve as an example.

\section{[5] Plautus Miles gloriosus 354}

Pal. praecepta facito ut memineris. Phil. totiens monere mirum est.

Pal. Make sure you remember my instructions.

Phil. I'm surprised that you remind me so often

[6] Plautus Menaechmi 344-345

Mes. ... nunc in istoc portu est nauis praedatoria, aps qua cauendum nobis sane censeo.

Sos. mones quidem hercle recte.

Mes. ... Now in that harbor there's a pirate ship which I think we need to be on our guard against.

Sos. You're giving me proper advice.

Finally, if the adviser's authority and/or expertise are markedly higher than the advisee's, as in the case of the cunning slave Palaestrio [7], the advisory acts are referred to as praecepta ('instructions'). In this example, the bindingness of the directive illocution is confirmed by the uptake of the hearer, who will obediently follow (parere) the described course of action. Pyrgopolinices conveys the idea that the source of knowledge is clearly his adviser, whose competence and expertise is foregrounded.

12 Latin monere derives from PIE *mon-eie- 'to make think of, remind' which is a causative suffixed form of the stem *men- 'to think' present in mens 'mind' and meminisse 'to remember' (see de Vaan 2008: 387 ). For the connection between reminding and admonishing being transparent for the interlocutors, see Plaut. Capt. 191: Erg. ... numquid uis? Heg. uenias temperi. Erg. memorem mones. ('Erg. ... Is there anything you want? Heg. Come early. Erg. You're reminding someone who remembers.'). 
[7] Plautus Miles gloriosus 1034-1036

Pyrg. iube adire. Pal. at scin quid tu facias? facito fastidi plenum, quasi non lubeat; me inclamato, quia [sic] tam te uolgo uolgem.

Pyrg. memini et praeceptis parebo.

Pyrg. Have her come here.

Pal. But do you know what you should do? Be full of disdain, as if you weren't interested. Shout at me because I publicize you to the public like this.

Pyrg. I remember it and I'll obey your instructions.

On the opposite end of the bindingness scale, I have found lay denominations of opinions and judgments, like sententia. Accordingly, this highly optional variant of advising is introduced by performative verbs used in assertions, such as censeo in [8]. Moreover, the advisee's autonomy of action, which is salient in this sub-type, will be related to particular (negative-)politeness strategies (see Section 4). Indirectness and minimal bindingness of the act of censere, however, may be perceived as vagueness and a sign of adviser's low personal commitment, as the reaction of the disappointed Demipho confirms below:

[8] Terence Phormio 452-459

Dem. dic nunc, Hegio.

Heg. ego sedulo hunc dixisse credo. uerum itast: quot homines tot sententiae: suos quoique mos. mihi non uidetur quod sit factum legibus rescindi posse; et turpe inceptust. Dem. dic, Crito.

Cri. ego amplius deliberandum censeo: res magnast. Heg. numquid nos uis? Dem. fecistis probe: incertior sum multo quam dudum.

Dem. Now you. Hegio.

Heg. I'm sure that he (pointing to Cratinus) has given you excellent advice. But the truth is, there are as many opinions as there are people; everyone has his own way of looking at things. My own view is that what has been done in accordance with the law cannot be rescinded, and it is dishonorable to try.

Dem. Now you, Crito. 
Cri. I suggest that this needs further deliberation. It's a weighty matter.

Heg. (to Demipho) Is that all?

Dem. (ironically) You've been very helpful. (aside) I'm even more uncertain than I was before.

At this point, it seems important to stress that the illocutionary force of advisory acts does not depend strictly on the linguistic tokens used by the adviser but, as Locher (2012: 4) reminds us, 'the embeddedness of the speech act in the wider speech event is crucial for its interpretation'. It follows that the expectations of the advisee also play a role in how the advice needs to be framed. In the next example [9], the young boy Chaerea is engaging in a 'trouble-telling sequence' with his slave Parmeno. After the servant has jokingly described some audacious course of action, his words are taken up in earnest by Chaerea, who calls the idea a great consilium. ${ }^{13}$

[9] Terence Eunuchus 376-378

Chae. dixisti pulchre: numquam uidi melius consilium dari.

$[\ldots]$

Par. quid agis? iocabar equidem.

Chae. It's a brilliant idea. I've never known better advice.

$[\ldots]$

Par. What are you thinking of? I was only joking.

The advisory acts discussed above can be further categorised by source of competence, i.e. by distinguishing whose expertise and knowledge is salient in designing the future course of action (see Figure 2). ${ }^{14}$ The acts of praecipere, consulere, and censere are anchored within the adviser's competence (with different degrees of bindingness). The monere-type of advice, by contrast, arguably implies that the advisee already knows the solution and only needs to be induced in order to implement the correct action.

13 Thus, Terence seems to be playfully remodelling a typical scene of a slave explaining the deceit to the adulescens who is in love-already Donatus was impressed by this technique (Don. ad Eun. 292, 356, 370). The contrast between planned and accidental action in Eunuchus was studied by Saylor (1975).

14 Accordingly, the competence management would be similar to what Riccioni et al. (2014: 53-54), drawing on Heritage (2012), call epistemic negotiations. The scholars use this framework to analyse face mitigation in Italian conversations. 
bindingness:

binding optional

source of competence: adviser praecipere consulere censere advisee monere

FIGURE 2 Classification of advisories in Roman comedy

The modifications of claimed and perceived source of competence, moreover, seem to run parallel to the negotiations of authority in the on-going advisory episode. The relationship between the interlocutors changes according to whether the advisee agrees to follow the proposed course of action (e.g. tuo consilio faciam) or is willing to admittedly rectify their behaviour out of their own intellectual resources (bene mones, etc.). Interestingly enough, this distinction is humorously exploited by Plautus in the following excerpt.

[10] Plautus Stichus 577-578

Epi. ... atque eccum tibi lupum in sermone: praesens esuriens adest. Pam. ludificemur hominem. Epi. capti consili memorem mones.

Epi. ... And look, here you have the wolf in the fable: he's present hungry.

Pam. Let's make fun of him.

Epi. You're reminding someone who remembers the plan that has been made.

The two brothers, Epignomus and Pamphilippus, see a somewhat tedious hanger-on approaching them on the stage. Pamphilippus makes a proposal to his brother to tease him, but Epignomus, in a turn of a typically Plautine stylistic colouring, responds that there is no need for proposals since his mind has already been made up and the consilium accepted, as if he himself had created the plan. Accordingly, he claims to be the source of the idea along with the competence and authority implied in launching the proposal.

\section{Face-Threat of Giving Advice}

The intricacies of the directive speech act system will prove relevant in the management of social relations. Brown and Levinson $\left({ }^{2} 1987\right)$, who formulated the universal model of politeness, were interested in the consequences that certain illocutions have on the speakers' self-presentation and how it affects their 
relationship. According to Goffman (1955: 213), the participants of an interaction claim a 'face' for themselves, i.e. a public image they construct (in close interrelation with each other) out of positive social values. Brown and Levinson ( ${ }^{2} 1987$ : 62) choose to reinterpret face as 'basic wants, which every member knows every other member desires, and which in general it is in the interests of every member to partially satisfy'. These face needs, in turn, can be subsumed into two categories: 'the desire to be ratified, understood, approved of, liked or admired' (positive-face wants) and the desire that one's own 'action is not impeded' (negative-face wants). In this politeness model, most of the speech acts interfere implicitly with either or both types of face wants and are called face-threatening acts.

According to Brown and Levinson ( $\left.{ }^{2} 1987: 65\right)$, giving advice, just as other directives, primarily threatens the addressee's negative-face want by indicating (in its worst possible interpretation) that the speaker is attempting to impede the hearer's freedom of action. The imposition on the advisee's autonomy strongly correlates with the degree of bindingness conveyed by the directive (sub-)type. On the other hand, performing an act whose felicity conditions include the hearer's benefit must also enhance their positive-face wants. The correct management of face depends on the estimation of interactional risk and possible face damage corresponding to a given advising situation.

Brown and Levinson ( $\left.{ }^{2} 1987: 74\right)$ proposed to calculate the level of face-threat on the basis of-broadly defined-factors of social distance (D) between the interlocutors, their relation of power $(\mathrm{P})$, as well as the ranking $(\mathrm{R})$ of imposition ascribed to the act. The last variable can be further elaborated on by the findings of Goldsmith and MacGeorge (2000: 256), who concluded that the perception of face-threat also depends on the types of goals attributed to advice givers and receivers, the types of problems (for which the degree of $\mathrm{P}$ and $\mathrm{D}$ may be relevant), as well as the content and the sequencing of an advice message.

As for the ranking of the imposition of advising in Roman culture, according to Burton (2004: 224), 'provision of candid advice' is essential for a healthy friendship among free-born of equal status (amicitia), being one of the reciprocal amical favours they perform..$^{15}$ From this set of mutual obligations and expectations, it follows that advisory acts between intimate characters are not very imposing - in fact, they may serve to enhance the social relation by flattering the positive face of both the adviser and the advisee. ${ }^{16}$ Thus, the young

\footnotetext{
15 See Plaut. Epid. 112-113 and Ter. Heaut. 416-419 on young and old men's in-group solidarity and mutual support.

16 In the case of the contemporary Spanish speaking community, Hernández-Flores (1999)
} 
citizen Charinus in [11] may freely and openly ask his friend for advice at the very beginning of the interaction, right after the greeting.

[11] Terence Andria $318-320$

Pam. Charinum uideo. salue. Cha. o salue, Pamphile. ad te aduenio spem, salutem, auxilium, consilium expetens.

Pam. neque pol consili locum habeo neque ad auxilium copiam.

Pam. It's Charinus. Good day.

Cha. Oh. good day Pamphilus. I am coming to you in need of hope, salvation, help, advice.

Pam. Heaven knows I'm in no position to advise and I've no means to help.

Still, the face threat in friendly advice can be considerably high, depending on the goals attributed to the advisers. The Plautine adulescens Lysiteles insists on marrying his friend's sister without a dowry as a way of helping him out in his financial troubles. The other youth, Lesbonicus, does not agree with this generous concession since he does not believe that his friend has his best interest at heart (male consulis ${ }^{17}$ ) (see [12]). From Lesbonicus' point of view, not giving a dowry will humiliate him and put his sister in a shameful marriage.

[12] Plautus Trinummus 633-636

Les. $\quad . .$. [qui] bene quom simulas facere mihi te, male facis, male consulis.

Lys. egone? Lesb. Tune. Lys. quid male facio? Lesb. quod ego nolo, id quom facis.

Lys. tuae rei bene consulere cupio. Lesb. tu [mihi] es melior quam egomet mihi?

sat sapio, satis in rem quae sint meam ego conspicio mihi.

indicates that candid advice is a responsibility of relations and does not need to be balanced against a need to symbolically recognise the other's autonomy.

17 Note that the verb consulere means 'to reflect on something', 'to ask for advice' as well as 'to have in mind the best interest of somebody'. It captures both facets of the advisory episode: reflecting on the problem and seeking to use someone else's expertise. Serving the benefit of the other party during the process is also implied. 
Les. $\quad$... While pretending to do me a good turn, you do me a bad one and treat me badly.

Lys. I?

Lesb. Yes, you.

Lys. In what respect am I doing you a bad turn?

Lesb. In doing what I don't want.

Lys. I wish to act in your best interest.

Lesb. Are you better to me than I am myself? I am intelligent enough, I can see well enough for myself what's in my best interest.

Reluctant to see good intentions in his interlocutor's act, Lesbonicus stresses his autonomy of decision and self-sufficiency (sat sapio 'I am intelligent enough'). Further on in the dialogue, Lysiteles does not hesitate to remind his friend that his impoverished conditions are related to his own indulgent lifestyle while urging him to change his mind. Harsh criticism is interwoven with a more insistent tone in this passage, and the friendly consilium turns into a strong admonishment (674 te moneo hoc etiam atque etiam 'I urge you again and again'). Lesbonicus, however, cannot appreciate his friend's concern and feels rebuked (68o tu obiurgans me 'while you're chiding me').

Furthermore, one could identify a direct relation between the role of expertise and the source of competence with the management of the participants' positive and negative faces in this scene. By considering the act of consulere unhelpful, the advisee implicitly questions the adviser's expertise, threatening his positive face. ${ }^{18}$ Hence, Lysiteles implies by his intensified use of moneo that the hearer should already know and appreciate the proposed course of action. On the other hand, Lesbonicus' competence first seemed damaged by Lysiteles' advice presented as a consilium — now the adviser is implying his resistance to admonishment. ${ }^{19}$

In conclusion, in this short episode we have identified some Roman (emic) correlates of Brown and Levinson's $\left({ }^{2} 1987: 76\right)$ social factors. In order to cal-

18 See also the criticism which the old man Chremes directs towards another senex in Ter. Heaut. 922-923: Chr. ... nonne id flagitiumst te aliis consilium dare, foris sapere, tibi non posse te auxiliarier? ('Chr. ... Isn't it a disgrace that you should give advice to others, be so wise to outsiders and be unable to help yourself?').

19 In the context of this admonitory dialogue, Burton (2004: 224) states that candour (libertas) is 'a potential minefield of misunderstanding and wounded feelings' due to which friends 'need to walk a fine line of admonition'. On the connection between frankness and monere in friendship, see also Cic. Amic. 44, briefly discussed in Hall (2009: 127128). 
culate the imposition of the act, the participants of the advisory episode in comedy have shown to be taking their intimacy, assumed authority (understood as expertise or experience), perceived interactional goals, and contents of the types of action contained in the advisory message into account, especially if the advice entailed elements of criticism. Advice, finally, proved to be facethreatening for all parties involved due to the fact that it changes the relation of power and distribution of competence among the interlocutors. ${ }^{20}$ Hence the 'riskiest' configurations in the social reality depicted by Plautus and Terence are: (i) peer-to-peer advice of free-born characters and (ii) low characters advising a non-intimate superior.

\section{Speech-Act Formulation and Im/politeness}

According to the classical theory of im/politeness, in case of any face-threatening acts, the face wants are addressed by specific formulation types (strategies). After reading through my corpus, I grouped the linguistic tokens of different advisory acts according to Brown and Levinson's $\left({ }^{2} 1987\right.$ : 68-70) classification. They organised the strategies into a hierarchy (I-IV) based on their level of imposition, where the lowest risk of face threat corresponds with the first major formulation type (I) and, respectively, the highest risk leads to the last strategy (IV) or to renouncing from doing the act altogether (which would be $\mathrm{v) \text {. }}$

Thus, giving advice baldly on-record (I) 'involves doing it in the most direct, clear, unambiguous and concise way possible'. I have listed all the forms which express the propositional content of telling others what, in a given situation, is right (decet, aequomst, etc.), what is better for them (melius est) or what they should do (opus est, oportet, and periphrastic gerundival construction). I included all of the imperative sentence types (present and future imperative forms, subjunctive) as well as the directive use of future indicative into this scheme. Even though these forms may convey different advisory acts in specific contexts, they nevertheless tend to imply a higher level of bindingness and are typically used as praecepta - see, for instance, the instructions in future imperative directed by Philto to his son in [13].

20 Similarly, in the context of giving advice, Hall (2009: 118) states that the interaction of Roman aristocrats in the times of Cicero can 'be viewed as an arena for competition rather than cooperation.' 
[13] Plautus Trinummus 297-298

Phil. ... meo modo et moribus uiuito antiquis, quae ego tibi praecipio, ea facito.

Phil. ... Live my way and by the old standards, do what I teach you.

Next, formulations can contain some redressive action 'that attempts to counteract the potential face damage' of the advisory act by a series of modifications and additions which are designed to address either the positive- or the negative-face wants (Brown and Levinson ${ }^{2} 1987$ : 69-70). The negativepoliteness strategies (III) entail, for instance, stressing the adviser's subjective point of view or the option of non-compliance by using the metalanguage of advice (Berger 2017: 270-271). Non-agentive advisory expressions seem to produce a similar redressive action (Brown and Levinson ${ }^{2} 1987$ : 191-194). As for positive-politeness mitigation (II), among the identified strategies, one could mention evoking a close bond with the advisee, searching for common ground, or including oneself in the realisation of the action. ${ }^{21}$ These are the strategies used by the senex Demea, who has recently experienced a self-induced transformation and is now trying out being extremely polite and considerate with others (see [14]). Interestingly enough, the change of his habitual speech pattern is achieved mainly through positive politeness while elsewhere in comedy old men are depicted as mostly concerned with negative-face wants (BarriosLech 2016: 56-57; Berger 2017: 271).

[14] Terence Adelphoe 948-955

Dem. ... bene nos aliquid facere illi decet.

Mic. quid facere? Dem. agellist hic sub urbe paullum quod locitas foras.

huic demus qui fruatur. Mic. paulum id autemst? Dem. si multumst, tamen

faciundumst: pro patre huic est, bonus est, noster est, recte datur, postremo nunc meum illud uerbum facio quod tu, Micio, bene et sapienter dixti dudum: 'uitium commune omniumst,

21 See Brown and Levinson $\left({ }^{2} 1987: 127-128\right)$ for the strategy of including both the speaker and the hearer in the activity. 
quod nimium ad rem in senecta attenti sumus'? hanc maculam nos decet

affugere. et dictumst uere et re ipsa fieri oportet.

Dem. ... We should do something for him.

Mic. Do what?

Dem. There's that small plot of land just outside the town which you let out. Let's give him the enjoyment of that.

Mic. That's a little plot?

Dem. Even if it's a large one, we should do it. He's like a father to the girl, he's a good man, he's one of us. It's a gift well given. When all's said and done, can't I adopt for myself the remark which you made just now, Micio, so wisely and so well? 'It's a common fault of all of us that in old age we are too worried about money.' We should avoid that reproach. It's sound advice and we should carry it out in practice.

While Demea formulates his advice to his brother, he repeatedly states that the decision is to be made together (nos decet; demus). The old man also addresses his interlocutor directly in order to demonstrate that the compliance would simply be following the advisee's own rules of conduct. This searching for common ground and indicating shared values serves, at the same time, to include face-enhancing praise (bene et sapienter dixti; dictumst uere). ${ }^{22}$ Still, one cannot overlook that these tokens of positive politeness are interwoven with mitigation that attends to negative-face wants, e.g. syntactical deletion of the addressee through non-agentive directive expressions (faciundumst; fieri oportet). Moreover, the advice is supplied by argumentation and justification by which the described course of action does not seem arbitrary nor peremptory. Accordingly, the redressive action in advisory acts proves to be a complex, sometimes multi-turn, procedure which, moreover, combines the positive- and the negative-politeness strategies in the same formulation. ${ }^{23}$

The last way of giving advice (IV) is doing it off-record, i.e. in such a way that 'it is not possible to attribute only one clear communicative intention

22 On compliments in Plautus and their contribution to linguistic politeness, see Unceta Gómez (2019). Here the act of praising seems to be ambiguous. Evoking Micio's own words and his rules of behaviour is also important for the plot: through his transformation, Demea seems to be trying to ridicule Micio's generosity and gentle spirit.

23 See also Hall (2009: 118-127), who discusses extensively the politeness strategies of giving advice through letters between Cicero and his peers. 
to the act' (Brown and Levinson ${ }^{2} 1987: 211$ ). Thus, the speaker avoids taking full responsibility for the illocution, leaving the interpretation of the utterance to the addressee. The off-record formulation, therefore, should be associated with the least binding advisory acts such as the act of censere or giving suggestions and hints, whose directive illocutionary force is derived inferentially from the context. The question launched by the banker Lyco in [15] violates the Gricean maxim of relevance (he does not contribute with any new information responding to Cappadox' inquiry) and of sincerity (he does not expect to be given an actual answer). ${ }^{24}$ By making a correct inference, Cappadox interprets the turn as a helpful admonishment (monere).

[15] Plautus Curculio 457-46o

Lyco argentum accipias, cum illo mittas uirginem.

Cap. quid quod iuratus sum? Lyco quid id refert tua, dum argentum accipias? Cap. qui monet quasi adiuuat.

Lyco Take your money and send the girl off with that man.

Cap. What about the oath I gave?

Lyco What does that matter to you so long as you receive your money?

Cap. He who advises helps, so to speak.

On the other hand, if the off-record strategy comes after an explicit request for advice, the comprehension process is more straightforward. For example, the young citizen Antipho is hinting to his slave Geta that he should steal the money from the youth's own father. The boy is expressing the advisory act by means of a declarative sentence type.

[16] Terence Phormio 540-542

Get. quid faciam? Ant. inuenias argentum. Get. cupio; sed id unde edoce.

Ant. pater adest hic. Get. scio. sed quid tum? Ant. ah! dictum sapienti sat est.

Get. itane? Ant. ita. Get. sane hercle pulchre suades.

24 For rhetorical questions as a frequent off-record strategy, see Brown and Levinson $\left({ }^{2} 1987\right.$ : 223-225). In describing the process of interpreting the off-record politeness strategy, the scholars refer to Grice's (1975) conversational maxims (Brown and Levinson ${ }^{2} 1987$ : 211-212, with a brief discussion). 
Get. By doing what?

Ant. Finding the money.

Get. I'd like to. But explain where?

Ant. My father's back home.

Get. I know, but what follows?

Ant. Oh! Can't you take a hint?

Get. Really?

Ant. Really.

Get. That is fine advice, for god's sake!

This category (IV) includes rhetorical questions (see [15]) or opinions and statements in declarative sentence types (see [16]).

The final calculation based on 154 advisory acts extracted from twelve comedies by Plautus and Terence are presented in Table 2. The proportions between illocutions formulated baldly on record $(49.4 \%)$ and with some kind of mitigation $(42.9 \%)$ are very similar. It is, however, worth keeping in mind that for these statistics I have only counted the elements of redressive action that are contained in the host advisory turn, although we have already seen that some face-work can be achieved in wider conversational surroundings.

It might be surprising that features of positive politeness are more frequently used than negative-face mitigation but the proportions are somehow tainted by certain formulations that seem to be combining both formulation strategies (grouped under 'mixed strategies'). ${ }^{25}$ This also makes the attempt to search for preferences in the distribution of a given strategy among the character types problematic - at least in a limited corpus such as this.

It may be useful to see if the contexts with a high imposition do indeed lead to 'polite' strategies of act realisation, especially in the first turn, where the concern for face is at its highest (see Section 3).

For the next quantitative analysis (see Table 3), I selected only the 'risky' configurations of advising: (i) peer-to-peer interactions of free-born characters and (ii) episodes of low-status character advising a superior. Even if face management plays an important role in (i), there is still a surprisingly high proportion of the least 'polite' formulation, baldly on-record ( $38.9 \%)$; it is even higher in contexts in (ii) $(63 \%)$.

25 The study of Goldsmith and MacGeorge (2000) tested the perception of the face-threat of giving advice in English. Similarly to the findings in this chapter, their sample advice messages were not seen by the language users as very threatening for the negative face, while the concern for the positive face was almost as important. 
TABLE 2 Formulation of advisory acts in the corpus distributed according to politeness strategies

\begin{tabular}{lccc}
\hline Speech-act expression & N $^{\circ}$ Politeness strategy & Total \\
\hline future indicative & 1 & (I) bald on-record & $76(49.4 \%)$ \\
simple imperative & 35 & & \\
present subjunctive & 14 & \\
future imperative & 6 & \\
periphrastic gerundival construction & 3 & \\
oportet / opus est "You should" & 8 & \\
decet / licet / aequom est "It's (only) right" & 3 & \\
satiust / meliust / potiust "It's better" & 6
\end{tabular}

+ seeking for common ground and values, evoking interpersonal bond

30 (II) positive-politeness $30(19.5 \%)$ mitigation (etc.)

combination of (II) and (III)

11 (II-III) mixed strategies $11(7.1 \%)$

+ stressing the subjectivity and optionality, deletion of the participants

25 (III) negative-politeness $25(16.2 \%)$ (etc.) mitigation

rhetorical questions

non-modal assertives

6 (IV) off-record

$12(7.8 \%)$

6

total 154

The predictive inaccuracies that Brown and Levinson's $\left({ }^{2} 1987\right)$ classic model exhibits were addressed by later methodological proposals. One of the reservations of the so-called discursive approach to im/politeness was that politeness should be viewed as a dynamic, participant-oriented concept that exceeds boundaries of a single utterance (see van der Bom and Mills 2015: 181-184, with further references). Thus, in the following section, I will test the potential value of 'polite' act formulation against its position in the dialogical sequence. 
TABLE 3 Politeness strategies in highly face-sensitive social contexts (tested in 12 Roman comedies)

\begin{tabular}{lclll}
\hline & $\begin{array}{c}\text { Baldly on } \\
\text { record (I) }\end{array}$ & $\begin{array}{l}\text { With redressive } \\
\text { action (II-III) }\end{array}$ & $\begin{array}{l}\text { Off-record } \\
(\mathbf{I V})\end{array}$ & $\begin{array}{l}\text { Total } \\
(100 \%)\end{array}$ \\
\hline $\begin{array}{c}\text { male-to-male } \\
\text { senex-to-senex }\end{array}$ & $14(38.9 \%)$ & $18(50.0 \%)$ & $4(11.1 \%)$ & 36 \\
$\begin{array}{l}\text { adulescens-to-adulescens } \\
\text { low-to-superior }\end{array}$ & 2 & 16 & 3 & \\
$\begin{array}{c}\text { seruus-to-senex } \\
\text { seruus-to-adulescens }\end{array}$ & $29(63.0 \%)$ & $15(32.6 \%)$ & $2(4.3 \%)$ & 46 \\
total & 9 & 5 & 2 & \\
& $43(52.4 \%)$ & $33(40.2 \%)$ & $6(7.3 \%)$ & 82 \\
\hline
\end{tabular}

In order to identify the conversational pattern of the advisory episode, one should first make a distinction between advice that is on-demand and advice that is not-sought-for. In case one, the interlocutor is searching for advice and the prototypical sequence of talk consists of at least three turns: (i) request for advice, (ii) granting of the advisory act, and (iii) evaluation and/or promise of compliance. In terms of CA, the first pair of turns is an adjacency pair, which, moreover, tends to be minimally expanded by a third, sequence-closing element or evaluation turn which is designed not to project any further withinsequence talk beyond itself' (Schegloff 2007: 118). This prototypical three-turn sequence appears throughout the entire chapter but is presented-for clarity—in the following excerpt [17]: a conversation between two old men, Laches and Phidippus.

\section{[17] Terence Hecyra 715-719}

Lach. quid ergo agam, Phidippe? quid das consili? (i)

Phi. quid agas? meretricem hanc primum adeundam censeo.

oremus, accusemus, grauius denique.

minitemur si cum illo habuerit rem postea.

Lach. faciam ut mones. (iii)

Lach. What shall I do, Phidippus? What's your advice?

Phi. What should you do? I suggest that we approach this mistress of his first. Let's appeal to her, put the accusation in front of her, and 
finally threaten some firm action if she has anything to do with him in the future.

Lach. I'll do as you suggest.

Interestingly, here, the request for advice includes two elements: the expression of doubt as to what course of action to take (quid ergo agam?) and an actual demand for a consilium. As far as distribution of competence is concerned, Laches is willing to confer the authority to his interlocutor and thus enhance his positive-face wants. Phidippus, however, by his turn-opening rhetorical question (quid agas?) seems to be implying that the right course of action is quite obvious. In reaction, Laches tries to save his own positive face by anchoring the idea within his own expertise: he reinterprets the act not as an adviser-oriented consilium but as a kind of admonishment (faciam ut mones). The act of compliance-perhaps significantly—does not contain any element of praising (e.g. bene/recte/pulchre mones), which normally enhances the adviser's positive-face. Despite these tensions in the distribution of authority, the adviser still addresses the face-needs of his interlocutor: he combines the deletion of the hearer in the first act (negative politeness) with the inclusion of himself in the realisation of the action (positive politeness) in the following formulations (oremus, accusemus, minitemur). ${ }^{26}$ Finally, it is worth noting that the advisory acts are ordered from more (periphrastic gerundival construction with censeo) to slightly less (subjunctive) 'polite' formulationsboth, however, with redressive action. Thus, the arrangement of the elements inside the turn proves to be relevant also for the calculation of interactional risk.

Another available option in the sequencing of the act is giving advice that is not requested explicitly and, hence, potentially unwanted. Menaechmus talks to the slave Messenio, thanking him for his help in a violent incident on the street. Since the servant mistakes Menaechmus for his own master, he uses the opportunity to suggest that, in exchange, he himself deserves to be liberated. This type of self-offered advice might be analysed not as a reaction to a request but as (i) an initiatory action (offering advice) paired with (ii) the following evaluation:

26 While Phidippus could have also meant that they should go meet the courtesan together, in the following scene, she is only approached by Laches (Ter. Hec. 731)—Phidippus never gets to talk to the woman. The polite extension of the reference in the directive is also confirmed by its first-person uptake ( faciam). 


\section{[18] Plautus Menaechmi 1021-1024}

Men. at tibi di semper, adulescens, quisquis es, faciant bene. nam apsque te esset, hodie numquam ad solem occasum uiuerem.

Mes. ergo edepol, si recte facias, ere, med emittas manu. (i)

Men. liberem ego te?

Men. May the gods always bless you, young man, whoever you are: if it hadn't been for you, I'd never have lived till sunset today.

Mes. Then if you were to do the right thing, master, you'd set me free.

Men. I should free you?

Risselada (1993: 57) remarks that compliance to directives on demand (i.e. in a second-pair-part position) is partially 'guaranteed' by the initiating turn. She concludes that the act in a first-pair-part position is more likely to contain tokens of politeness. Analogously, it follows from the discussion on face-threat in section 3 that this variant of sequence includes a higher level of imposition. All the constraints mentioned until now that shape the predictions on politeness seem to be at work in Messenio's formulation. The servant, while giving unsolicited advice on a serious matter (his manumission) to a person he takes for his master, chooses the positive-politeness strategy. Messenio addresses the master directly (ere) and he appeals to values (recte facere) he presumes his interlocutor shares. ${ }^{27}$

This rule may also be verified in a single interaction. In [19], the slave Stasimus is called after by his master, but-unwilling to look back-he cannot recognise him. The first unsolicited advisory act launched by the servant is formulated baldly on-record with a moral-evaluative expression (meliust + inf.). The next act, however, which comes after an explicit request (quid ago?), contains a more binding token: an unmitigated imperative. The socially defined imposition should not have changed significantly over one turn of talk; therefore, much the same value of politeness may be conveyed through different linguistic tokens, depending on different conversational contexts.

27 For the positive-politeness strategy of presuming that the hearer has the same values as the speaker, see Brown and Levinson ( ${ }^{2} 1987$ : 123-124). 
[19] Plautus Trinummus 106o-1063

Char. aha nimium, Stasime, saeuiter!

Stas. emere meliust quoi imperes. Char. pol ego emi atque argentum dedi; sed si non dicto audiens est, quid ago? Stas. da magnum malum.

Char. bene mones, ita facere certum est.

Char. Ah, Stasimus, you're behaving too violently!

Stas. It's better to buy someone to order around.

Char. I did buy someone and paid money; but if he doesn't obey me, what am I to do?

Stas. Give him a big thrashing.

Char. You're giving me good advice, I'm resolved to act accordingly.

Still, if during a face-sensitive social interaction the character launches unsolicited and unmitigated advisory turns, there should, as an alternative to mitigation, be some face-managing mechanisms. One such politeness-motivated phenomenon may be localised in the act's verbal embedding and, more specifically, in the design of its turn-host.

Firstly, I argue that postponing the advisory act within the turn might have a redressive function. This effect is most visible if the adviser reverses the order of advice and its justification or explanation, which—as I have pointed out before-avoids the peremptoriness of the directive (see Section 3). In the trouble-telling sequence [20], the slave Byrria uses a bald on-record formulation (subjunctive uelis) but arguably mitigates the imposition by first presenting the reasons for offering this particular piece of advice. The postponed advisory act of a slave talking to his young master may be compared with the next example [21], where the old father fronts his urgent advice (directed to his daughter in danger) in a turn-initial position. Here, the content of the act and its early placement inside a turn is more important than any politeness feature.

[20] Terence Andria 305-306

quaeso edepol, Charine, quoniam non potest id fieri quod uis, id uelis quod possis.

Please, Charinus, for god's sake, since you can't have what you want, want what you can have. 


\section{[21] Plautus Menaechmi 850-851}

fuge domum, quantum potest, ne hic te optundat.

Run off home as fast as possible so that he doesn't beat you.

Moving on to more face-sensitive contexts, in [22] the speaker introduces the act by means of a mitigating preface that prepares the ground for a baldly onrecord performed directive: the advice given by the doctor. The introductory part is even separated from the rest of the speaker's utterance by a verse-final pause. This mechanism allows the adviser to create a fictitious scenario in which his advice is actually a reactive action—-towards his own words.

[22] Plautus Menaechmi 946

scin quid facias optimum est?

ad me face uti deferatur.

Do you know what you'd better do? Have him taken to my place.

[23] Plautus Menaechmi 1023

ergo edepol, si recte facias, ere, med emittas manu.

Then if you were to do the right thing, master, you'd set me free.

The imposition that self-selection in advisory acts constitutes can also be partially compensated through cohesive linguistic elements. Messenio (see [23] and [18] above), for instance, conveys that the advice is a logical consequence (ergo) of the advisee's previous talk.

Consequently, the positioning of advisory acts in the conversation might also be relevant for the politeness prediction and the actual interpersonal impact of certain types of formulation. Apart from high-imposition social configurations for speech activity, one should also look into 'risky' conversational contexts. The examples presented in this section suggest that the highest facethreat should be ascribed to unsolicited advice, fronted in turn-initial position, first in a series of acts (if there is any) and without perceivable connection to the previous conversational material. 
TABLE 4 Correlation between parameters of advisory acts and politeness strategy

(orders)

praecipere (I) baldly on-record

consilum dare (II-III) with redressive action consulere

monere

censere (IV) off-record

(statements)

\section{$6 \quad$ Conclusions}

This chapter proposes a wider pragmatic approach to advising in Roman comedy in order to better grasp its theoretical elusiveness as a protean illocution type with multiple expressive means. First, the phenomenon was analysed as a chain of directive sub-types (advisory acts), differentiated according to the factor of bindingness and distribution of the competence. Arguably the latter distinction-between the acts attributed only to adviser's intellectual resources (praeceptum, consilium, and sententiae) and the knowledge already stored in the advisee's mind (monere) — is more important than, for instance, the (English) one between advice and warning.

Further, I have tentatively connected the formulation of the advisory acts with Brown and Levinson's $\left({ }^{2} 1987\right)$ politeness strategies. Certain ways of compensating the face-threat tend to correspond with particular types of illocution identified in the corpus (see Table 4) since a more direct (i.e., baldly on-record) formulation normally conveys more binding speech acts, while the off-record strategy sometimes results in assertive-like expressions of the advisory act.

Despite the correlations, it was often necessary to stress that the illocution type, just like the politeness value, was a result of a rather complex interaction between social (power relation, distance, ranking of imposition) and contextual (verbal surrounding) constraints. Regarding the latter, I hope to have demonstrated some correlations between the act formulation, its evaluation in terms of politeness, and its position in a wider discursive environment: inside 
a sequence, in an adjacency pair, and inside a turn. Such discourse-oriented analysis might arguably be a more nuanced approach to investigate the ways of doing politeness and, from a wider perspective, of doing things with words in dramatic dialogues.

\section{References}

Austin, J.L., ( ${ }^{2} 1975$ [1962]), How to Do Things with Words, Oxford.

Bach, K. \& Harnish, R.M., (1979), Linguistic Communication and Speech Acts, Cambridge, Mass.

Barrios-Lech, P., (2016), Linguistic Interaction in Roman Comedy, Cambridge.

Barsby, J., (2001), Terence. Comedies, 2 vols., Cambridge, Mass./London.

Berger, Ł., (2017), 'The Old Man and Linguistic Politeness in the Comedies of Plautus', Symbolae Philologorum Posnaniensium Graecae et Latinae 27, 249-273.

Bom, I. van der \& Mills, S., (2015), 'A Discursive Approach to the Analysis of Politeness Data', Journal of Politeness Research 11, 179-206.

Brown, P. \& Levinson, S.C., ( ${ }^{2} 1987$ [1978]), Politeness: some Universals in Language Usage, Cambridge.

Burton, P.J., (2004), 'Amicitia in Plautus: a Study of Roman Friendship Processes', American Journal of Philology 125, 209-243.

Cabrillana, C., (2016), 'Directives in Latin Comedy: Pragmatics, Dramatic Role and Social Status', Journal of Latin Linguistics 15, 179-214.

Dickey, E., (2012), 'How to Say "Please” in Classical Latin', Classical Quarterly 62, 731748.

Dickey, E., (2016), 'Politeness in Ancient Rome: Can it Help us Evaluate Modern Politeness Theories?', Journal of Politeness Research 12, 197-220.

Goffman, E., (1955), 'On Face-work: an Analysis of Ritual Elements in Social Interaction', Psychiatry 18, 213-231.

Goldsmith, D. \& MacGeorge, E., (2000), 'The Impact of Politeness and Relationship on Perceived Quality of Advice about a Problem', Human Communication Research 26, 234-263.

Grice, H.P., (1975), 'Logic and Conversation', in P. Cole \& J.L. Morgan (eds.), Speech Acts, New York, $41-58$.

Hall, J., (2009), Politeness and Politics in Cicero's Letters, Oxford.

Heritage, J., (2012), 'Epistemics in Action: Action Formation and Territories of Knowledge', Research on Language \& Social Interaction 45, 1-29.

Hernández-Flores, N., (1999), 'Politeness Ideology in Spanish Colloquial Conversation: the Case of Advice', Pragmatics 9, 37-49.

Hoffmann, M.E., (1983), 'Conversation Openings in the Comedies of Plautus', in H. Pink- 
ster (ed.), Latin Linguistics and Linguistic Theory. Proceedings of the ist International Colloquium on Latin Linguistics (Amsterdam, April 1981), Amsterdam, 217-226.

Levinson, S.C., (1983), Pragmatics, Cambridge/New York.

Locher, M.A., (2012), 'Introduction to Advice in Discourse', in H. Limberg \& M.A. Locher (eds.), Advice in Discourse, Amsterdam/Philadelphia, 1-27.

Melo, W. de, (2011-2013), Plautus. Comedies, 5 vols., Cambridge, Mass./London.

Müller, R., (1997), Sprechen und Sprache. Dialoglinguistische Studien zu Terenz, Heidelberg.

Raccanelli, R., (1998), L'amicitia nelle commedie di Plauto: un'indagine antropologica, Bari.

Riccioni, I., Bongelli, R., \& Zuczkowski, A., (2014), 'Mitigation and Epistemic Positions in Troubles Talk: the Giving Advice Activity in Close Interpersonal Relationships. Some Examples from Italian', Language \& Communication 39, 51-72.

Risselada, R., (1993), Imperatives and Other Directive Expressions in Latin: a Study in the Pragmatics of a Dead Language, Amsterdam.

Saylor, C.F., (1975), 'The Theme of Planlessness in Terence's Eunuchus', Transactions of the American Philological Association 105, 297-311.

Schegloff, E.A., (2007), Sequence Organization in Interaction, Cambridge.

Searle, J.R., (1969), Speech Acts: an Essay in the Philosophy of Language, Cambridge.

Searle, J.R., (1976), 'A Classification of Illocutionary Acts', Language in Society 5, 1-23.

Unceta Gómez, L., (2009), La petición verbal en latín. Estudio léxico, semántico y pragmático, Madrid.

Unceta Gómez, L., (2018), 'Gli studi sulla (s)cortesia linguistica in latino. Possibilità di analisi e proposte per il futuro', Studi e Saggi Linguistici 56(2), 9-37.

Unceta Gómez, L. (2019), 'I complimenti e il loro contributo all'espressione della cortesia linguistica nelle commedie di Plauto', Dionysus ex machina 1o, 283-311.

Vaan, M. de, (2008), Etymological Dictionary of Latin and the Other Italic Languages, Leiden/Boston. 